Article

\title{
Terpenoids from the Octocoral Sinularia gaweli
}

\section{Wun-Jie Lin ${ }^{1,2, \dagger}$, Tung-Ying Wu ${ }^{3, \dagger}$, Tzu-Rong Su ${ }^{4,5}$, Zhi-Hong Wen ${ }^{6}$, Jih-Jung Chen ${ }^{7}$,

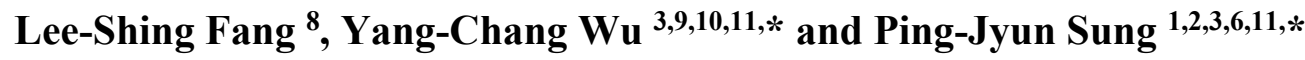

1 Graduate Institute of Marine Biology, National Dong Hwa University, Pingtung 944, Taiwan; E-Mail: abcdewq213@hotmail.com

2 National Museum of Marine Biology \& Aquarium, Pingtung 944, Taiwan

3 Chinese Medicine Research and Development Center, China Medical University Hospital, Taichung 404, Taiwan; E-Mail: kuma0401@gmail.com

4 Department of Beauty Science, Meiho University, Pingtung 912, Taiwan; E-Mail: a081002@mail.tsmh.org.tw

5 Antai Medical Care Cooperation Antai Tian-Sheng Memorial Hospital, Pingtung 928, Taiwan

6 Department of Marine Biotechnology and Resources, Asia-Pacific Ocean Research Center, National Sun Yat-sen University, Kaohsiung 804, Taiwan; E-Mail: wzh@mail.nsysu.edu.tw

7 Graduate Institute of Pharmaceutical Technology \& Department of Pharmacy, Tajen University, Pingtung 907, Taiwan; E-Mail: jjchen@mail.tajen.edu.tw

8 Department of Sport, Health and Leisure, Cheng Shiu University, Kaohsiung 833, Taiwan; E-Mail: 1sfang@csu.edu.tw

9 School of Pharmacy, College of Pharmacy, China Medical University, Taichung 404, Taiwan

${ }^{10}$ Center for Molecular Medicine, China Medical University Hospital, Taichung 404, Taiwan

11 Graduate Institute of Natural Products, Kaohsiung Medical University, Kaohsiung 807, Taiwan

$\dagger$ These authors contributed equally to this work.

* Authors to whom correspondence should be addressed;

E-Mails: yachwu@mail.cmu.edu.tw (Y.-C.W.); pjsung@nmmba.gov.tw (P.-J.S.);

Tel.: +886-4-220-57513 (Y.-C.W.); +886-8-882-5037 (P.-J.S.);

Fax: +886-4-220-60248 (Y.-C.W.); +886-8-882-5087 (P.-J.S.).

Academic Editors: Vassilios Roussis and Efstathia Ioannou

Received: 8 July 2015 / Accepted: 10 August 2015 / Published: 18 August 2015

Abstract: Two eudesmane sesquiterpenoids, verticillatol (1) and 5a-acetoxy-4(14)eudesmene-1 $\beta$-ol (2) and two cembrane diterpenoids, (-)-leptodiol acetate (3) and sinulacembranolide A (4) were isolated from the octocoral Sinularia gaweli and compounds 
2-4 are new isolates. The structures of new terpenoids $2-\mathbf{4}$ were elucidated by spectroscopic methods and by comparison the spectral data with those of known analogues. Terpenoid 4 was found to inhibit the accumulation of the pro-inflammatory inducible nitric oxide synthase (iNOS) protein of the lipopolysaccharide (LPS)-stimulated RAW264.7 marcophage cells.

Keywords: Sinularia gaweli; eudesmane; cembrane; octocoral; iNOS

\section{Introduction}

Octocorals belonging to the Sinularia genus have been well-recognized as marine organisms containing large quantities of terpenoid metabolites that exhibit varying degrees of bioactivities [1,2]. Our previous investigation on the soft coral Sinularia gaweli (Verseveldt, 1978, phylum Cnidaria, class Anthozoa, order Alcyonacea, family Alcyoniidae). (Figure 1) had afforded norcembranoidal diterpenes and steroid analogues [3-5]. Our continuing studies on this soft coral has, again, led to the isolation of four terpenoid metabolites, including two eudesmane sesquiterpenoids, verticillatol (1) [6] and 5 $\alpha$-acetoxy4(14)-eudesmene-1 $\beta$-ol (2) and two cembranes, (-)-leptodiol acetate (3) and sinulacembranolide A (4) (Figure 1), and compounds $\mathbf{2} \mathbf{- 4}$ are new isolates. In this paper, the isolation, structure determination and anti-inflammatory activity of compounds $\mathbf{1}-\mathbf{4}$ are described.

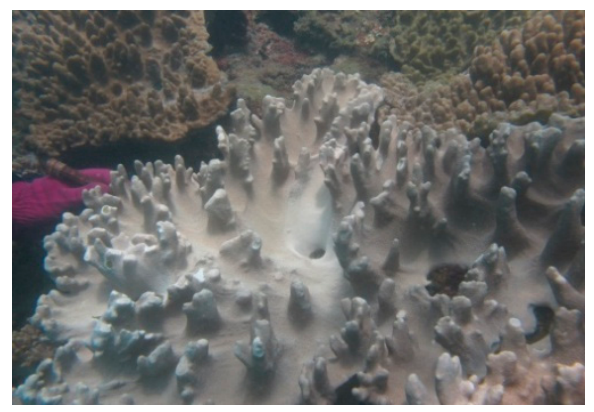

Sinularia gaweli

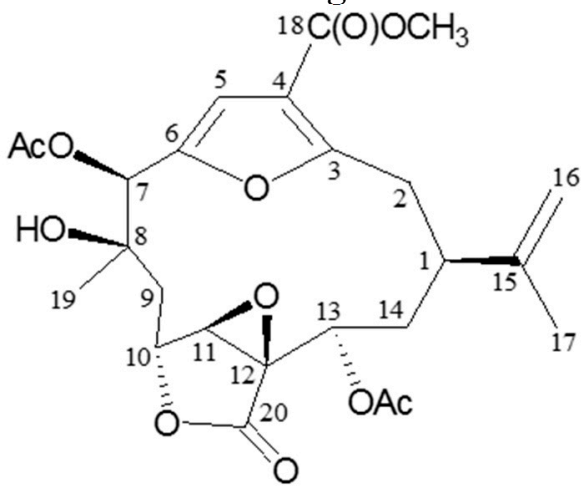

3

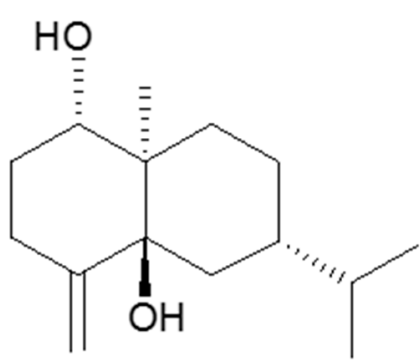

1

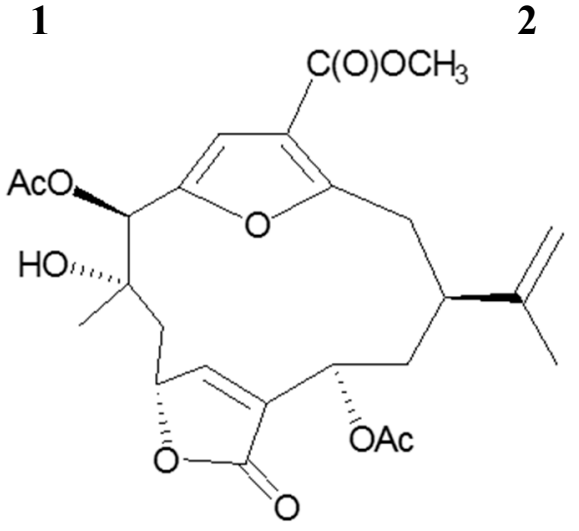

4

Figure 1. The soft coral Sinularia gaweli and the structures of verticillatol (1); $5 \alpha$-acetoxy4(14)-eudesmene-1 $\beta$-ol (2); (-)-leptodiol acetate (3); and sinulacembranolide A (4). 


\section{Results and Discussion}

A known eudesmane sesquiterpenoid, verticillatol (1), was obtained in this study. This compound had been obtained from a Vietnam plant Litsea verticullata [6]. The NMR data and rotation value of 1 were identical to those of verticillatol described previously.

$5 \alpha$-Acetoxy-4(14)-eudesmene-1 $\beta$-ol (2) was isolated as a colorless oil and the molecular formula for this compound was determined to be $\mathrm{C}_{17} \mathrm{H}_{28} \mathrm{O}_{3}$ (four units of unsaturation) using HRESIMS $\left(\mathrm{C}_{17} \mathrm{H}_{28} \mathrm{O}_{3}+\mathrm{Na}\right.$, $m / z$ 303.19293, calculated 303.19307). Comparison of the ${ }^{13} \mathrm{C} N M R$ and distortionless enhancement by polarization transfer (DEPT) data with the molecular formula indicated that there was an exchangeable proton, which required the presence of a hydroxy group. This deduction was supported by a broad absorption in the IR spectrum at $3465 \mathrm{~cm}^{-1}$. The IR spectrum also showed a strong band at $1735 \mathrm{~cm}^{-1}$, consistent with the presence of an ester group. From the ${ }^{1} \mathrm{H}$ and ${ }^{13} \mathrm{C}$ NMR spectra (Table 1), 2 was found to possess an acetoxy group $\left(\delta_{\mathrm{H}} 2.03,3 \mathrm{H}, \mathrm{s} ; \delta_{\mathrm{C}} 168.9, \mathrm{C} ; 21.8, \mathrm{CH}_{3}\right)$. An additional unsaturated functionality was indicated by ${ }^{13} \mathrm{C}$ resonances at $\delta \mathrm{C} 111.6\left(\mathrm{CH}_{2}-14\right)$ and $145.1(\mathrm{C}-4)$, suggesting the presence of an exocyclic carbon-carbon double bond. Thus, the proposed skeleton of 2 was suggested to be a bicyclosesquiterpenoid.

Table 1. ${ }^{1} \mathrm{H}\left(400 \mathrm{MHz}, \mathrm{CDCl}_{3}\right)$ and ${ }^{13} \mathrm{C}\left(100 \mathrm{MHz}, \mathrm{CDCl}_{3}\right) \mathrm{NMR}$ data, ${ }^{1} \mathrm{H}-{ }^{1} \mathrm{H}$ COSY and HMBC correlations for sesquiterpenoid 2.

\begin{tabular}{|c|c|c|c|c|}
\hline Position & $\delta_{\mathrm{H}}$ Multiplicity $(J$ in $\mathrm{Hz})$ & סc, Multiplicity & ${ }^{1} \mathrm{H}--^{1} \mathrm{H}$ COSY & НМBC \\
\hline 1 & $4.00 \mathrm{dd}(12.0,4.8)$ & $72.9, \mathrm{CH}$ & $\mathrm{H}_{2}-2$ & $C-2,-10,-15$ \\
\hline $2 \alpha$ & $1.85 \mathrm{~m}$ & $30.9, \mathrm{CH}_{2}$ & $\mathrm{H}-1, \mathrm{H}-2 \beta, \mathrm{H}_{2}-3$ & n. o. \\
\hline$\beta$ & $1.55 \mathrm{~m}$ & - & $\mathrm{H}-1, \mathrm{H}-2 \alpha, \mathrm{H}_{2}-3$ & $C-1,-3$ \\
\hline $3 \alpha$ & $2.22 \mathrm{~m}$ & $30.2, \mathrm{CH}_{2}$ & $\mathrm{H}_{2}-2, \mathrm{H}-3 \beta$ & $C-1,-2,-4,-5,-14$ \\
\hline$\beta$ & $1.26 \mathrm{~m}$ & - & $\mathrm{H}_{2}-2, \mathrm{H}-3 \alpha$ & n. o. \\
\hline 4 & - & 145.1, C & - & - \\
\hline 5 & - & $87.3, \mathrm{C}$ & - & - \\
\hline $6 \alpha$ & 2.61 br d (14.4) & $28.5, \mathrm{CH}_{2}$ & H-6 $\beta$ & $C-5,-10$ \\
\hline$\beta$ & $1.41 \mathrm{dd}(14.4,12.4)$ & & H-6 $\alpha$, H-7 & $C-7,-8$ \\
\hline 7 & $1.26 \mathrm{~m}$ & $38.6, \mathrm{CH}$ & $\mathrm{H}_{2}-6, \mathrm{H}_{2}-8, \mathrm{H}-11$ & C-9 \\
\hline $8 \alpha$ & $1.22 \mathrm{~m}$ & 23.6, $\mathrm{CH}_{2}$ & $\mathrm{H}-7, \mathrm{H}-8 \beta, \mathrm{H}_{2}-9$ & C-7, -9 \\
\hline$\beta$ & $1.59 \mathrm{~m}$ & - & $\mathrm{H}-7, \mathrm{H}-8 \alpha, \mathrm{H}_{2}-9$ & n. o. \\
\hline 9 & $1.70 \mathrm{~m}$ & $30.4, \mathrm{CH}_{2}$ & $\mathrm{H}_{2}-8$ & $C-7,-8,-15$ \\
\hline 10 & - & $43.3, \mathrm{C}$ & - & - \\
\hline 11 & $1.47 \mathrm{~m}$ & $32.5, \mathrm{CH}$ & $\mathrm{H}-7, \mathrm{H}_{3}-12, \mathrm{H}_{3}-13$ & C-8 \\
\hline 12 & $0.90 \mathrm{~d}(6.8)$ & 19.6, $\mathrm{CH}_{3}$ & H-11 & $C-7,-11,-13$ \\
\hline 13 & $0.89 \mathrm{~d}(6.8)$ & $19.9, \mathrm{CH}_{3}$ & H-11 & $C-7,-11,-12$ \\
\hline $14 \mathrm{a}$ & $5.05 \mathrm{~s}$ & $111.6, \mathrm{CH}_{2}$ & $\mathrm{H}-14 \mathrm{~b}$ & $\mathrm{C}-3,-5$ \\
\hline $\mathrm{b}$ & $4.90 \mathrm{~s}$ & - & $\mathrm{H}-14 \mathrm{a}$ & $\mathrm{C}-3,-4,-5$ \\
\hline 15 & $0.79 \mathrm{~s}$ & $12.3, \mathrm{CH}_{3}$ & - & $C-1,-5,-9,-10$ \\
\hline 5 -OAc $\left(5^{\mathrm{a}}\right)($ the $\mathrm{C}=\mathrm{O})$ & - & $168.9, \mathrm{C}$ & - & - \\
\hline $5-\mathrm{OAc}\left(5^{\mathrm{b}}\right)$ (the $\left.\mathrm{Me}\right)$ & $2.03 \mathrm{~s}$ & $21.8, \mathrm{CH}_{3}$ & - & $C-5^{\mathrm{a}}$ \\
\hline
\end{tabular}

n. o. = not observed; $\mathrm{COSY}=$ correlation spectroscopy; $\mathrm{HMBC}=$ heteronuclear multiple bond connectivity;

$5^{\mathrm{a}}=$ acetate carbonyl of 5 -acetoxy group; $5^{\mathrm{b}}=$ acetate methyl of 5 -acetoxy group. 
From the ${ }^{1} \mathrm{H}-{ }^{1} \mathrm{H}$ COSY and HMBC spectrum of $\mathbf{2}$ (Table 1), permitted elucidation of the main eudesmane carbon skeleton. The relative configuration of 2 was elucidated by means of a NOESY (nuclear overhauser effect spectroscopy) experiment (Figure 2). The NOEs of H-9 $\alpha$ to H-1 and H-7 $\alpha$ revealed the hydroxy group at $\mathrm{C}-1$ and isopropyl group at $\mathrm{C}-7$ to be $\beta$-oriented. The NOEs between $\mathrm{H}_{3}-15 / \mathrm{H}-2 \beta, \mathrm{H}_{3}-15 / \mathrm{H}-6 \beta$, and $\mathrm{H}_{3}-15 / \mathrm{H}-8 \beta$ assigned the methyl group at $\mathrm{C}-10$ as $\beta$. By comparison of the rotation value of compound $2\left([\alpha]_{\mathrm{D}}^{25}+75(c 0.93, \mathrm{MeOH}) ;[\alpha]_{\mathrm{D}}^{25}+25\left(c 0.93, \mathrm{CHCl}_{3}\right)\right)$ with those of 1 (verticillatol) $\left([\alpha]_{\mathrm{D}}^{25}-41.2\left(c 0.13, \mathrm{CHCl}_{3}\right)\right)$ [6] and the enantiomer of $\mathbf{1}, 4(15)$-eudesmene-1 $\beta, 5 \alpha$-diol $\left([\alpha]_{\mathrm{D}}^{23}+108(c 0.8, \mathrm{MeOH})\right)$ [7] (In this reference, the alphabetical orders for C-14 and C-15 in this compound should be exchanged from the IUPAC recommendation), suggested that the acetoxy group at C-5 should be $\alpha$-oriented. Since the absolute configuration of 4(15)-eudesmene-1 $\beta, 5 \alpha$-diol had been determined by modified Mosher's method [7], we were able to assign the absolute configurations of all the chiral centers of $\mathbf{2}$ as $1 R, 5 S, 7 R, 10 S$. Based on the above findings, the structure of $\mathbf{2}$ was, therefore, determined to be $5 \alpha$-acetoxy-4(14)-eudesmene- $1 \beta$-ol.

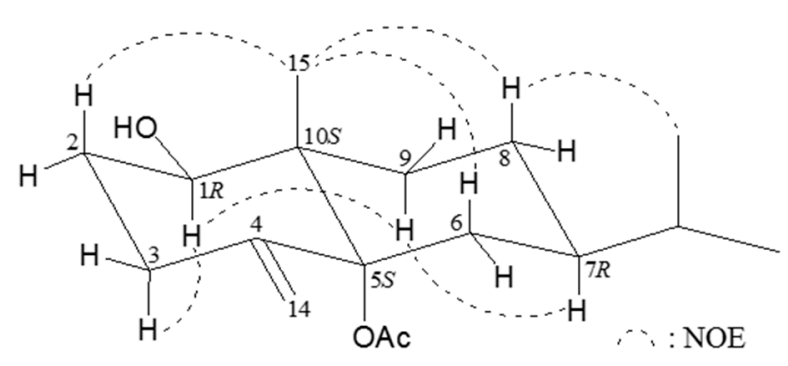

Figure 2. Important nuclear overhauser effect spectroscopy (NOESY) correlations for compound 2.

The spectral $\left({ }^{1} \mathrm{H},{ }^{13} \mathrm{C}\right.$ NMR and IR) data of 3 were in full agreement with those of a known cembrane analogue, leptodiol acetate, which was isolated from a Panama gorgonian coral identified as Leptogorgia sp. [8]. However, the optical rotation value of $\mathbf{3}\left([\alpha]_{\mathrm{D}}^{25}-24\left(c 0.33, \mathrm{CHCl}_{3}\right) ;[\alpha]_{\mathrm{D}}^{25}-10(c 0.33\right.$, $\left.\mathrm{CH}_{2} \mathrm{Cl}_{2}\right)$ ) was substantially different from that of leptodiol acetate $\left([\alpha]_{\mathrm{D}}^{20}+27\left(c 0.49, \mathrm{CH}_{2} \mathrm{Cl}_{2}\right)\right)$; indicating that cembranoid 3 is an enantiomer of leptodiol acetate and assigned as (-)-leptodiol acetate.

The molecular formula for cembranoid 4 (sinulacembranolide A) was determined to be $\mathrm{C}_{25} \mathrm{H}_{30} \mathrm{O}_{10}$ (11 units of unsaturation) using HRESIMS $\left(\mathrm{C}_{25} \mathrm{H}_{30} \mathrm{O}_{10}+\mathrm{Na}, m / z\right.$ 513.17338, calcd. 513.17312). Absorption for hydroxy and carbonyl groups at 3481, 1756, and $1721 \mathrm{~cm}^{-1}$ were observed in the IR spectrum. The ${ }^{13} \mathrm{C}$ NMR and DEPT spectra of 4 (Table 2) showed the presence of 25 carbon signals assigned to $5 \times \mathrm{CH}_{3}$ (one methoxy group, two from acetyl groups), $4 \times \mathrm{CH}_{2}$ (one olefinic), $6 \times \mathrm{CH}$ (two olefinics and three oxymethines) and 10 quaternary carbons (four carbonyls and five olefinics). ${ }^{1} \mathrm{H}$ and ${ }^{13} \mathrm{C}$ NMR data of 4 (Table 2) were similar with those of $\mathbf{3}$, particularly the chemical shifts for 11,12-epoxy group in $3\left(\delta_{\mathrm{H}} 4.10,1 \mathrm{H}\right.$, br s, H-11; $\left.\delta_{\mathrm{C}} 63.0, \mathrm{CH}-11 ; 59.0, \mathrm{C}-12\right)$ were replaced by a carbon-carbon double bond $\left(\delta_{\mathrm{H}} 6.16,1 \mathrm{H}, \mathrm{d}, J=1.2 \mathrm{~Hz}, \mathrm{H}-11 ; \delta_{\mathrm{C}} 154.0, \mathrm{CH}-11 ; 129.8, \mathrm{C}-12\right)$ for molecule 4. Connectivity information obtained from $2 \mathrm{D}$ NMR, including ${ }^{1} \mathrm{H}-{ }^{1} \mathrm{H}$ COSY and $\mathrm{HMBC}$ experiments, unambiguously determined the planar structure of 4 (Table 2). The relative configuration of 4 was elucidated from NOESY correlations (Figure 3). In the NOESY experiment for $\mathbf{4}$, it was found that one of the methylene protons at $\mathrm{C}-2\left(\delta_{\mathrm{H}} 2.82\right)$ exhibited a correlation with $\mathrm{H}-1$, but not with $\mathrm{H}-13$ and, therefore, it was assigned as $\mathrm{H}-2 \alpha$, and the other $\mathrm{C}-2$ proton $\left(\delta_{\mathrm{H}} 3.57\right)$ as $\mathrm{H}-2 \beta$. H-13 showed correlations with $\mathrm{H}-2 \beta$ and $\mathrm{H}-11$, but not with $\mathrm{H}-1$, and $\mathrm{H}-11$ showed a correlation with $\mathrm{H}-10$, as well 
as a small coupling $(J=1.2 \mathrm{~Hz})$ detected between $\mathrm{H}-10$ and H-11, indicating the dihedral angle between $\mathrm{H}-10$ and $\mathrm{H}-11$ is approximately $90^{\circ}$ and the geometry of the C-11/12 carbon-carbon double bond was $Z$ form and $\mathrm{C}-10$ possessing an relative configuration $R^{*}$-form. $\mathrm{H}_{3}-19$ correlated with $\mathrm{H}-10$ and $\mathrm{H}-11$, but not with $\mathrm{H}-7$, indicating that Me-19 and $\mathrm{H}-7$ were $\beta$ - and $\alpha$-oriented at C-8 and C-7, respectively. From the above evidence, the relative configuration of chiral carbons of 4 were assumed to be $1 S^{*}, 7 R^{*}$, $8 S^{*}, 10 R^{*}$, and $13 S^{*}$.

To the best of our knowledge, the C-7, C-8 vicinal diol-based cembranoid analogues are rarely found [9]. In previous studies on $S$. gaweli had afforded an interesting norcembranoid, sinulanorcembranolide A [3], and the biosynthetic pathway for sinulanorcembranolide A was proposed in a later study [10]. This observation is in agreement with the observation that cembrane diterpenoids from Alcyonacea have opposite configuration at C-1 compared to those obtained from Gorgonacea [11].

Table 2. ${ }^{1} \mathrm{H}\left(400 \mathrm{MHz}, \mathrm{CDCl}_{3}\right)$ and ${ }^{13} \mathrm{C}\left(100 \mathrm{MHz}, \mathrm{CDCl}_{3}\right) \mathrm{NMR}$ data, ${ }^{1} \mathrm{H}-{ }^{1} \mathrm{H}$ COSY and HMBC correlations for cembrane 4.

\begin{tabular}{|c|c|c|c|c|}
\hline Position & $\delta_{\mathrm{H}}$ Multiplicity $(J$ in $\mathrm{Hz})$ & $\delta_{c}$, Multiplicity & ${ }^{1} \mathrm{H}-{ }^{1} \mathrm{H}$ COSY & HMBC \\
\hline 1 & 2.32 ddd $(10.8,10.8,3.2)$ & $41.5, \mathrm{CH}$ & $\mathrm{H}_{2}-2, \mathrm{H}_{2}-14$ & $\mathrm{C}-17$ \\
\hline $2 \alpha$ & $2.82 \mathrm{~d}(15.2)$ & $31.9, \mathrm{CH}_{2}$ & H-2 $\beta$ & $C-1,-3,-4,-14,-15$ \\
\hline$\beta$ & $3.57 \mathrm{dd}(15.2,10.8)$ & - & H-1, H-2 $\alpha$ & C-1, -14 \\
\hline 3 & - & 160.9, C & - & - \\
\hline 4 & & $115.5, \mathrm{C}$ & - & - \\
\hline 5 & $6.65 \mathrm{~d}(0.8)$ & $109.1, \mathrm{CH}$ & H-7 & $C-3,-4,-6$ \\
\hline 6 & - & $149.2, \mathrm{C}$ & - & - \\
\hline 7 & $5.54 \mathrm{br} \mathrm{s}$ & 76.1, $\mathrm{CH}$ & H-5 & $C-5,-6,-8,-9,-19,-7^{\mathrm{a}}$ \\
\hline 8 & - & $72.6, \mathrm{C}$ & - & - \\
\hline $9 \alpha$ & $1.91 \mathrm{dd}(14.8,11.2)$ & $42.9, \mathrm{CH}_{2}$ & $\mathrm{H}-9 \beta, \mathrm{H}-10$ & $C-7,-8,-10$ \\
\hline$\beta$ & $2.67 \mathrm{dd}(14.8,5.6)$ & - & $\mathrm{H}-9 \alpha, \mathrm{H}-10$ & $C-7,-8,-10,-11$ \\
\hline 10 & $4.95 \mathrm{ddd}(11.2,5.6,1.2)$ & 77.6, $\mathrm{CH}$ & $\mathrm{H}_{2}-9, \mathrm{H}-11$ & $\mathrm{C}-9,-11,-12$ \\
\hline 11 & $6.16 \mathrm{~d}(1.2)$ & $154.0, \mathrm{CH}$ & H-10 & $\mathrm{C}-10,-12,-13,-20$ \\
\hline 12 & - & $129.8, \mathrm{C}$ & - & - \\
\hline 13 & $5.52 \mathrm{dd}(11.2,4.8)$ & $66.7, \mathrm{CH}$ & $\mathrm{H}_{2}-14$ & $C-11,-12,-14,-13^{a}$ \\
\hline $14 \alpha$ & $2.63 \mathrm{ddd}(11.2,11.2,3.2)$ & 36.1, $\mathrm{CH}_{2}$ & $\mathrm{H}-1, \mathrm{H}-13, \mathrm{H}-14 \beta$ & n. o. \\
\hline$\beta$ & $1.90 \mathrm{ddd}(11.2,10.8,4.8)$ & - & $\mathrm{H}-1, \mathrm{H}-13, \mathrm{H}-14 \alpha$ & $C-1,-2,-12,-13$ \\
\hline 15 & - & $148.4, \mathrm{C}$ & - & - \\
\hline 16 & $4.82 \mathrm{br} \mathrm{s}$ & $110.6, \mathrm{CH}_{2}$ & $\mathrm{H}_{3}-17$ & $C-1,-15,-17$ \\
\hline 17 & $1.81 \mathrm{~s}$ & $20.7, \mathrm{CH}_{3}$ & $\mathrm{H}_{2}-16$ & $C-1,-15,-16$ \\
\hline 18 & - & $163.5, \mathrm{C}$ & - & - \\
\hline 19 & $1.47 \mathrm{~s}$ & $20.1, \mathrm{CH}_{3}$ & - & $\mathrm{C}-7,-8,-9$ \\
\hline 20 & - & $169.5, \mathrm{C}$ & - & - \\
\hline 7-OAc $\left(7^{\mathrm{a}}\right)($ the $\mathrm{C}=\mathrm{O})$ & - & 169.6, C & - & - \\
\hline 7-OAc $\left(7^{\mathrm{b}}\right)($ the $\mathrm{Me})$ & $2.17 \mathrm{~s}$ & $20.9, \mathrm{CH}_{3}$ & - & $C-7^{a}$ \\
\hline $13-\mathrm{OAc}\left(13^{\mathrm{a}}\right)($ the $\mathrm{C}=\mathrm{O})$ & - & $170.3, \mathrm{C}$ & - & - \\
\hline $13-\mathrm{OAc}\left(13^{\mathrm{b}}\right)($ the $\mathrm{Me})$ & $1.99 \mathrm{~s}$ & 21.0, $\mathrm{CH}_{3}$ & - & $\mathrm{C}-13^{\mathrm{a}}$ \\
\hline $18-\mathrm{OCH}_{3}$ & $3.88 \mathrm{~s}$ & $51.9, \mathrm{CH}_{3}$ & - & $\mathrm{C}-18$ \\
\hline
\end{tabular}

n. o. $=$ not observed; $7^{\mathrm{a}}=$ acetate carbonyl of 7 -acetoxy group; $7^{\mathrm{b}}=$ acetate methyl of 7 -acetoxy group; $13^{\mathrm{a}}=$ acetate carbonyl of 13 -acetoxy group; $13^{\mathrm{b}}=$ acetate methyl of 13 -acetoxy group. 


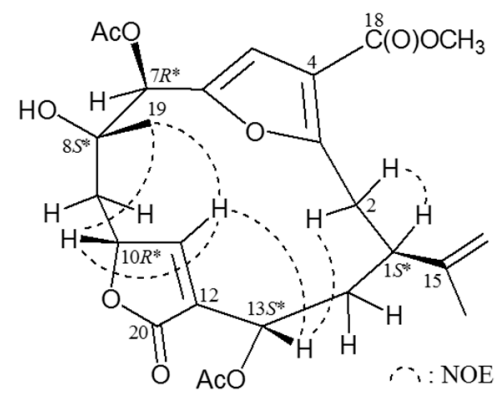

Figure 3. NOESY (nuclear overhauser effect spectroscopy) correlations of compound 4.

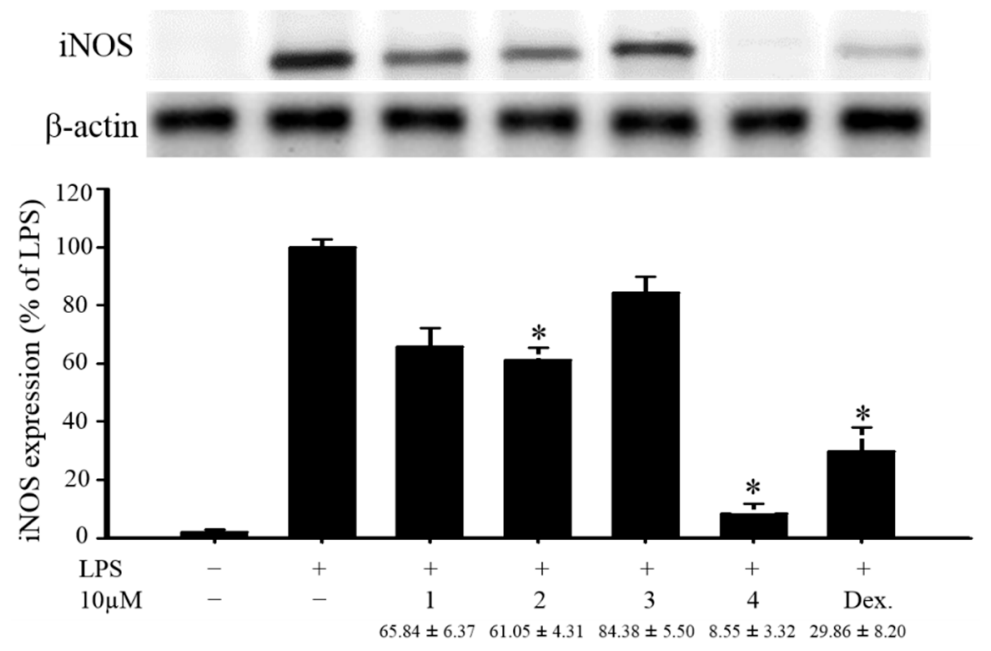

(A)

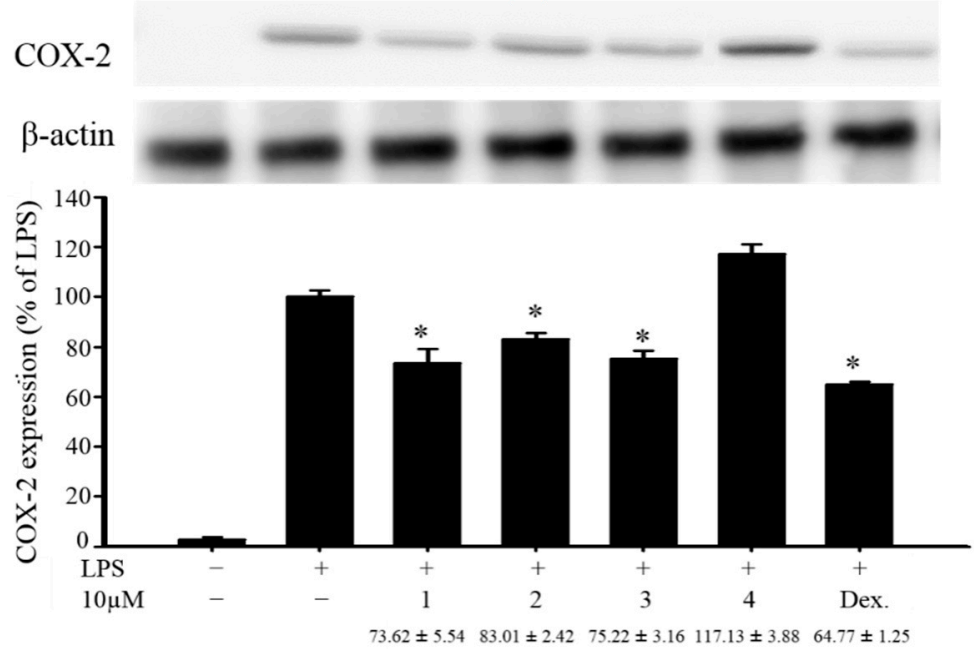

(B)

Figure 4. Effects of compounds 1-4 on pro-inflammatory iNOS and COX-2 protein expression in LPS-stimulated murine macrophage cell line RAW264.7. (A) Relative density of iNOS immunoblot; (B) relative density of COX-2 immunoblot. The relative intensity of the LPS-stimulated group was taken to be $100 \%$. Band intensities were quantified by densitometry and are indicated as the percent change relative to that of the LPS-stimulated group. Compound 4 and dexamethasone (Dex.) significantly inhibited LPS-induced iNOS protein expression in macrophage. The experiment was repeated three times. $(* p<0.05$, significantly different from the LPS-stimulated group). 
In the in vitro anti-inflammatory activity test, the upregulation of the pro-inflammatory inducible nitric oxide synthase (iNOS) and cyclooxygenase-2 (COX-2) proteins expression of LPS (lipopolysaccharide) -stimulated RAW264.7 macrophage cells was evaluated using immunoblot analysis. At a concentration of $10 \mu \mathrm{M}$, compound 4 was found to significantly reduce the levels of iNOS to $8.55 \% \pm 3.32 \%$, relative to the control cells stimulated with LPS only (Figure 4). Thus, compound 4 might be promising as an anti-inflammatory agent, as this compound did not exhibit cytotoxicity to RAW264.7 macrophage cells.

\section{Experimental Section}

\subsection{General Experimental Procedures}

Optical rotation values were measured with a Jasco P-1010 digital polarimeter (Japan Spectroscopic Corporation, Tokyo, Japan). IR spectra were recorded on a Jasco FT-4100 FT-IR spectrometer (Japan Spectroscopic Corporation, Tokyo, Japan); peaks are reported in $\mathrm{cm}^{-1}$. NMR spectra were recorded on a Varian Mercury Plus 400 NMR spectrometer (Varian Inc., Palo Alto, CA, USA) using the residual $\mathrm{CHCl}_{3}$ signal $\left(\delta_{\mathrm{H}} 7.26 \mathrm{ppm}\right)$ as the internal standard for ${ }^{1} \mathrm{H} \mathrm{NMR}$ and $\mathrm{CDCl}_{3}\left(\delta_{\mathrm{C}} 77.1 \mathrm{ppm}\right)$ for ${ }^{13} \mathrm{C}$ NMR. Coupling constants $(J)$ are given in Hz. ESIMS and HRESIMS were recorded using a Bruker 7 Tesla solariX FTMS system (Bruker, Bremen, Germany). Column chromatography was performed on silica gel (230-400 mesh, Merck, Darmstadt, Germany). TLC was carried out on precoated Kieselgel $60 \mathrm{~F}_{254}$ (0.25 mm, Merck, Darmstadt, Germany); spots were visualized by spraying with 10\% $\mathrm{H}_{2} \mathrm{SO}_{4}$ solution, followed by heating. Normal-phase HPLC (NP-HPLC) was performed using a system comprised of a Hitachi L-7110 pump (Hitachi Ltd., Tokyo, Japan) and a Rheodyne 7725 injection port (Rheodyne LLC, Rohnert Park, CA, USA). Two normal-phase columns (Supelco Ascentis ${ }^{\circledR}$ Si Cat \#: $581514-\mathrm{U}, 25 \mathrm{~cm} \times 10 \mathrm{~mm}$ and 581515-U, $25 \mathrm{~cm} \times 21.2 \mathrm{~mm}, 5 \mu \mathrm{m}$, Sigma-Aldrich, St. Louis, MO, USA) were used for HPLC. Reverse phase HPLC (RP-HPLC) was performed using a system comprised of a Hitachi L-2130 pump (Hitachi Ltd., Tokyo, Japan), a Hitachi L-2455 photodiode array detector (Hitachi Ltd., Tokyo, Japan), a Rheodyne 7725 injection port (Rheodyne LLC., Rohnert Park, CA, USA). A reverse phase column (Supelco Ascentis ${ }^{\circledR} \mathrm{Si}$ Cat \#: $581343-\mathrm{U}, 25 \mathrm{~cm} \times 10.0 \mathrm{~mm}, 5 \mu \mathrm{m}$, Sigma-Aldrich, St. Louis, MO, USA) was used for RP-HPLC.

\subsection{Animal Material}

Specimens of the octocoral Sinularia gaweli (Verseveldt, 1978) were collected by hand using self-contained underwater breathing apparatus (SCUBA) equipment off the coast of Sansiantai, Taitung county, Taiwan on 7 May 2013, and stored in a freezer $\left(-20^{\circ} \mathrm{C}\right)$ until extraction. A voucher specimen (NMMBA-TWSC-13031) was deposited in the National Museum of Marine Biology \& Aquarium, Taiwan.

\subsection{Extraction and Isolation}

Sliced bodies of Sinularia gaweli (wet weight 2794 g, dry weight 756 g) were extracted with ethyl acetate (EtOAc). The EtOAc layer (20.5 g) was separated on silica gel and eluted using $n$-hexane/EtOAc (stepwise, $100: 1 \rightarrow 99: 1 \rightarrow 95: 5 \rightarrow 9: 1 \rightarrow 4: 1 \rightarrow 7: 3 \rightarrow 3: 2 \rightarrow 1: 1 \rightarrow 2: 3 \rightarrow 3: 7 \rightarrow 1: 4 \rightarrow 1: 9 \rightarrow$ pure EtOAc, each fraction $\times 2 \mathrm{~L}$ ) to yield 21 fractions, A-U, by thin layer chromatography (TLC) analysis. Fraction $\mathrm{G}$ (collected from the fraction eluted using $n$-hexane/EtOAc 4:1) was chromatographed on NP-HPLC 
using a mixture of $n$-hexane and acetone (4:1) to afford nine fractions, G1-G9. Fraction G5 was separated by NP-HPLC using a mixture of dichloromethane (DCM) and acetone (50:1, flow rate: $1.0 \mathrm{~mL} / \mathrm{min})$ to afford $2\left(2.8 \mathrm{mg}, t_{\mathrm{R}}=38 \mathrm{~min}\right)$. Fraction $\mathrm{H}$ (collected from the fraction eluted using $n$-hexane/EtOAc 7:3) was chromatographed on NP-HPLC using a mixture of $n$-hexane and EtOAc (3:1) to afford 14 fractions, H1-H14. Fraction H9 was separated by NP-HPLC using a mixture of $n$-hexane and acetone (5:1, flow rate: $0.5 \mathrm{~mL} / \mathrm{min}$ ) to afford $1\left(0.5 \mathrm{mg}, t_{\mathrm{R}}=80 \mathrm{~min}\right.$ ). Fraction $\mathrm{N}$ (collected from the fraction eluted using $n$-hexane/EtOAc 1:1) was separated on silica gel and eluted using $n$-hexane and acetone (stepwise, 6:1-1:1) to yield 16 fractions, N1-N16. Fraction N11 was separated by on NP-HPLC using a mixture of $n$-hexane and acetone (2:1) to afford $3\left(6.6 \mathrm{mg}, t_{\mathrm{R}}=23 \mathrm{~min}\right)$. Fraction $\mathrm{P}$ (collected from the fraction eluted using $n$-hexane/EtOAc 2:3) was chromatographed on NP-HPLC using a mixture of $n$-hexane and acetone (2:1) to afford 12 fractions, P1-P12. Fraction P7 was separated by RP-HPLC using a mixture of methanol and $\mathrm{H}_{2} \mathrm{O}(60: 40$, flow rate: $3.0 \mathrm{~mL} / \mathrm{min})$ to afford $4\left(1.4 \mathrm{mg}, t_{\mathrm{R}}=120 \mathrm{~min}\right)$.

Verticillatol (1): colorless oil; $[\alpha]_{\mathrm{D}}^{26}-113\left(c 0.17, \mathrm{CHCl}_{3}\right)$ (reference [5], $[\alpha]_{\mathrm{D}}^{25}-41.2\left(c 0.13, \mathrm{CHCl}_{3}\right)$ ); IR (neat) $v_{\max } 3444 \mathrm{~cm}^{-1} ;{ }^{1} \mathrm{H}$ and ${ }^{13} \mathrm{C}$ NMR data were found to be in full agreement with those reported previously [6].

$5 \alpha$-Acetoxy-4(14)-eudesmene-1 $\beta$-ol (2): colorless oil; $[\alpha]_{\mathrm{D}}^{25}+75(c 0.93, \mathrm{MeOH})\left([\alpha]_{\mathrm{D}}^{25}+25(c 0.93\right.$, $\left.\mathrm{CHCl}_{3}\right)$ ); IR (neat) $v_{\max } 3465,1735 \mathrm{~cm}^{-1} ;{ }^{1} \mathrm{H}\left(400 \mathrm{MHz}, \mathrm{CDCl}_{3}\right)$ and ${ }^{13} \mathrm{C}\left(100 \mathrm{MHz}, \mathrm{CDCl}_{3}\right) \mathrm{NMR}$ data, see Table 1; ESIMS: $m / z 303[\mathrm{M}+\mathrm{Na}]^{+}$; HRESIMS: $m / z 303.19293$ (calcd for $\mathrm{C}_{17 \mathrm{H}_{28} \mathrm{O}_{3}+}+$ $\mathrm{Na}, 303.19307)$.

(-)-Leptodiol acetate (3): white solid; mp $183-185{ }^{\circ} \mathrm{C} ;[\alpha]_{\mathrm{D}}^{25}-24\left(c 0.33, \mathrm{CHCl}_{3}\right)\left([\alpha]_{\mathrm{D}}^{25}-10(c 0.33\right.$, $\mathrm{CH}_{2} \mathrm{Cl}_{2}$ )); IR (neat) $v_{\max } 3502,1785,1734 \mathrm{~cm}^{-1} ;{ }^{1} \mathrm{H}$ and ${ }^{13} \mathrm{C}$ NMR data were found to be in full agreement with those reported previously [8]; ESIMS: $m / z 529$ [M + Na] $]^{+}$; HRESIMS: $m / z 529.16777$ (calcd for $\left.\mathrm{C}_{25} \mathrm{H}_{30} \mathrm{O}_{11}+\mathrm{Na}, 529.16803\right)$.

Sinulacembranolide A (4): white solid; mp $120-123{ }^{\circ} \mathrm{C}$; $[\alpha]_{\mathrm{D}}^{25}-10\left(c 0.07, \mathrm{CHCl}_{3}\right)$; IR (neat) $v_{\max }$ 3481, 1756, $1721 \mathrm{~cm}^{-1} ;{ }^{1} \mathrm{H}\left(400 \mathrm{MHz}, \mathrm{CDCl}_{3}\right)$ and ${ }^{13} \mathrm{C}\left(100 \mathrm{MHz}, \mathrm{CDCl}_{3}\right)$ NMR data, see Table 2; ESIMS: $m / z 513[\mathrm{M}+\mathrm{Na}]^{+}$; HRESIMS: $m / z 513.17338$ (calcd for $\mathrm{C}_{25} \mathrm{H}_{30} \mathrm{O}_{10}+\mathrm{Na}, 513.17312$ ).

\subsection{In Vitro Anti-Inflammatory Assay}

Murine macrophage (RAW264.7) cell line was purchased from ATCC. In vitro anti-inflammatory activity of compounds 1-4 was measured by examining the inhibition of lipopolysaccharid (LPS)-induced up-regulation of pro-inflammatory inducible nitric oxide synthase (iNOS) and cyclooxygenase-2 (COX-2) protein expression in macrophage cells using Western blotting analysis [12-14]. Briefly, inflammation in macrophages was induced by incubating them for $16 \mathrm{~h}$ in a medium containing only LPS $(10 \mathrm{ng} / \mathrm{mL})$ without compounds. For anti-inflammatory activity assay, compounds $\mathbf{1 - 4}$ and dexamethasone $(10 \mu \mathrm{M})$ were added the cells 10 min before LPS challenge. The cells then underwent Western blot analysis. The immunoreactivity data are calculated with respect to the average optical density of the corresponding LPS-stimulated group. For statistical analysis, the data were analyzed by a one-way analysis of variance (ANOVA), followed by the Student-Newman-Keuls post hoc test for multiple comparisons. A significant difference was defined as a $p$ value of $<0.05$. 


\section{Conclusions}

Our studies on Sinularia gaweli for the extraction of additional natural substances, have led to the isolation of two eudesmane sesquiterpenoids, verticillatol (1) and $5 \alpha$-acetoxy-4(14)-eudesmene-1 $\beta$-ol (2) and two cembranoids, (-)-leptodiol acetate (3) and sinulacembranolide A (4) and compounds 2-4 are new isolates. Terpenoid $\mathbf{4}$ is potentially anti-inflammatory and may become a lead compound in marine anti-inflammatory drug development. The octocoral Sinularia gaweli will be transplanted to culturing tanks located in the National Museum of Marine Biology \& Aquarium, Taiwan, for extraction of additional natural products to establish a stable supply of bioactive material.

\section{Acknowledgments}

This research was supported by grants from the National Dong Hwa University; the Kaohsiung Chang Gung Memorial Hospital (Grant No. CMRPG8C1281); the National Museum of Marine Biology \& Aquarium; the Asia-Pacific Ocean Research Center, National Sun Yat-sen University; the Ministry of Science and Technology (Grant No. NSC 103-2911-I-002-303; MOST 104-2911-I-002-302; MOST 103-2325-B-039-008; MOST 103-2325-B-039-007-CC1; MOST 104-2325-B-291-001; MOST 104-2320-B-291-001-MY3; MOST 103-2325-B-291-001; MOST 104-2320-B-291-001-MY3 and NSC 101-2320-B-291-001-MY3); the National Health Research Institutes (NHRI-EX103-10241BI), and in part from the grant from Chinese Medicine Research Center, China Medical University (the Ministry of Education, the Aim for the Top University Plan), Taiwan, awarded to Yang-Chang Wu and Ping-Jyun Sung.

\section{Author Contributions}

Yang-Chang $\mathrm{Wu}$ and Ping-Jyun Sung designed the whole experiment and contributed to manuscript preparation; Wun-Jie Lin and Tung-Yin $\mathrm{Wu}$ researched data and wrote the manuscript. Tzu-Rong Su, Zhi-Hong Wen, Jih-Jung Chen and Lee-Shing Fang analyzed the data and performed data acquisition.

\section{Conflicts of Interest}

The authors declare no conflict of interest.

\section{References}

1. Chen, W.-T.; Li, Y.; Guo, Y.-W. Terpenoids of Sinularia soft corals: Chemistry and bioactivity. Acta Pharm. Sin. B 2012, 2, 227-237.

2. Rocha, J.; Peixe, L.; Gomes, N.C.M.; Calado, R. Cnidarians as a source of new marine bioactive compounds-An overview of the last decade and future steps for bioprospecting. Mar. Drugs 2011, 9, 1860-1886.

3. Yen, W.-H.; Su, Y.-D.; Chang, Y.-C.; Chen, Y.-H.; Chen, Y.-H.; Dai, C.-F.; Wen, Z.-H.; Su, J.-H.; Sung, P.-J. Sinulanorcembranolide A, a novel norcembranoidal diterpene from the octocoral Sinularia gaweli. Tetrahedron Lett. 2013, 54, 2267-2270. 
4. Hu, L.-C.; Yen, W.-H.; Su, J.-H.; Chiang, M.Y.-N.; Wen, Z.-H.; Chen, W.-F.; Lu, T.-J.; Chang, Y.-W.; Chen, Y.-H.; Wang, W.-H.; et al. Cembrane derivatives from the soft corals, Sinularia gaweli and Sinularia flexibilis. Mar. Drugs 2013, 11, 2154-2167.

5. Yen, W.-H.; Chen, W.-F.; Cheng, C.-H.; Dai, C.-F.; Lu, M.-C.; Su, J.-H.; Su, Y.-D.; Chen, Y.-H.; Chang, Y.-C.; Chen, Y.-H.; et al. A new 5 $\alpha, 8 \alpha$-epidioxysterol from the soft coral Sinularia gaweli. Molecules 2013, 18, 2895-2903.

6. Hong, V.D.; Tan, G.T.; Zhang, H.-J.; Tamez, P.A.; Hung, N.V.; Cuong, N.M.; Soejarto, D.D.; Fong, H.H.S.; Pezzuto, J.M. Natural anti-HIV agents-part I: (+)-Demethoxyepiexcelsin and verticillatol from Litsea verticillata. Phytochemistry 2002, 59, 325-329.

7. Kitajima, J.; Suzuki, N.; Satoh, M.; Watanabe, M. Sesquiterpenoids of Torilis japonica fruit. Phytochemistry 2002, 59, 811-815.

8. Díaz-Marrero, A.R.; Porras, G.; Cueto, M.; D’Croz, L.; Lorenzo, M.; San-Martín, A.; Darias, J. Leptogorgolide, a biogenetically interesting 1,4-diketo-cembranoid that reinforces the oxidation profile of C-18 as taxonomical marker for octocorals. Tetrahedron 2009, 65, 6029-6033.

9. Li, Y.; Pattenden, G. Perspectives on the structural and biosynthetic interrelationships between oxygenated furanocembranoids and their polycyclic congeners found in corals. Nat. Prod. Rep. 2011, 28, 1269-1310.

10. Palframan, M.J.; Pattenden, G. Searching for radical intermediates and pathways implied in the biosynthesis of some polycyclic cembranoids. A new plausible mechanism for the origin of sinulanorcembranolide A in the coral Sinularia gyrosa. Tetrahedron Lett. 2013, 54, 6822-6855.

11. Rodríguez, A.D.; Li, Y.; Dhasmana, H.; Barnes, C.L. New marine cembrane diterpenoids isolated from the Caribbean gorgonian Eunicea mammosa. J. Nat. Prod. 1993, 56, 1101-1113.

12. Huang, S.-Y.; Chen, N.-F.; Chen, W.-F.; Hung, H.-C.; Lee, H.-P.; Lin, Y.-Y.; Wang, H.-M.; Sung, P.-J.; Sheu, J.-H.; Wen, Z.-H. Sinularin from indigenous soft coral attenuates nociceptive responses and spinal neuroinflammation in carrageenan-induced inflammatory rat model. Mar. Drugs 2012, 10, 1899-1919.

13. Jean, Y.-H.; Chen, W.-F.; Sung, C.-S.; Duh, C.-Y.; Huang, S.-Y.; Lin, C.-S.; Tai, M.-H.; Tzeng, S.-F.; Wen, Z.-H. Capnellene, a natural marine compound derived from soft coral, attenuates chronic constriction injury-induced neuropathic pain in rats. Br. J. Pharmacol. 2009, 158, 713-725.

14. Jean, Y.-H.; Chen, W.-F.; Duh, C.-Y.; Huang, S.-Y.; Hsu, C.-H.; Lin, C.-S.; Sung, C.-S.; Chen, I.-M.; Wen, Z.-H. Inducible nitric oxide synthase and cyclooxygenase-2 participate in anti-inflammatory and analgesic effects of the natural marine compound lemnalol from Formosan soft coral Lemnalia cervicorni. Eur. J. Pharmacol. 2008, 578, 323-331.

(C) 2015 by the authors; licensee MDPI, Basel, Switzerland. This article is an open access article distributed under the terms and conditions of the Creative Commons Attribution license (http://creativecommons.org/licenses/by/4.0/). 